\title{
ОДГОВОР НАУКЕ НА ЕПИДЕМИЈУ ИЗАЗВАНУ САРС-КОВ-2 ВИРУСОМ
}

\author{
др Марина Соковић ${ }^{11}$, \\ проф. др Татјана Пекмезовић² и радна група ${ }^{3}$
}

Апстракт: Министарство просвете, науке и технолошког развоја (МПНТР) Владе Републике Србије је након проглашења ванредног стања у Републици Србији одмах предузело низ активности како би се укључило у борбу државе против пандемије ковида 19. Формирана је радна група за прикупљање информација из научне литературе које се односе на епидемију изазвану САРс-КОВ-2 вирусом, а чине је научници са института и факултета из целе Србије. Њихов задатак био је да анализирају најрелевантније научне радове, као и најновије поуздане изворе информација, и да о кључним сазнањима на тему ковида 19 свакодневно достављају извештаје државном секретару за науку, који је затим исте прослеђивао кабинету премијерке Владе Републике Србије, Кризном штабу и лекарском тиму. Радна група је поред научних информација објављених у међународним часописима пласирала и предлоге истраживача и научноистраживачких институција (НИО) и указала на могућност и спремност научника да своје знање пласирају кроз разне тестове

1 Министарство просвете, науке и технолошког развоја, Влада Републике Србије, Његошева 12, 11000 Београд, Србија. e-mail: marina.sokovic@mpn.gov.rs

2 Универзитет у Београду, Медицински факултет, Институт за епидемиологију, Катедра за епидемиологију, Др. Суботића 8, 11000 Београд, Србија. e-mail: tatjana.pekmezovic@med.bg.ac.rs

3 Милош Мојовић, Факултет за физичку хемију, Универзитет у Београду (БУ), Стеван Благојевић, Институт за општу и физичку хемију (БУ), Петар Кнежевић, Природноматематички факултет, Универзитет у Новом Саду, Ђорђе Миљковић, ИБИСС (БУ), Радивоје Продановић, Хемијски факултет (БУ), Милош Вићић, Физички факултет (БУ), Бранко Јовчић, Биолошки факултет, (БУ), Жељко Мијаиловић, ФМН Крагујевац, Александар Белић, Институт за физику (БУ), Сергеј Томић, ИНЕП (БУ), Бојан Бонџић, ИХТМ (БУ), Марина Динић, Медицински факултет, Универзитет у Нишу, Мирослав Савић, Фармацеутски факултет (БУ), Соња Павловић, ИМГГИ (БУ), Маријана Стојановић, ТОРЛАК, Сања Глишић, ИНН Винча, Весна Шуљагић, Медицински факултет ВМА, Небојша Кладар, Медицински факултет, Универзитет у Новом Саду, Ивана Гађански, Беосенс Нови Сад, Олгица Ђурковић Ђаковић, ИМИ (БУ), Лидија Матија, Машински факултет (БУ). 
и третмане. Препозната је важност и могућност примене неких предлога од стране научника, као што су коришћења крвне плазме у третману средње тешких ковид 19 пацијената, третман оболелих интравенским имуноглобулинима, формирање биобанке узорака од пацијената оболелих од ковида 19, производња домаћих серолошких и ЕЛИСА тестова, извођење националне епидемиолошке студије, синтеза протеинског комплекса антигена који учествује у инфекцији, студија специфичности имунског одговора код пацијената са различитим клиничким степеном ковида 19. Све поменуте студије су у току и за сада се успешно примењују на пацијентима. Поред свакодневног извештавања радна група је послала и предложила Кризном штабу најновије препоруке и протоколе за дезинфекцију простора, коришћење заштитне опреме, превенцију, тестове и терапију, и наставља даље са својим радом. Министарство је регрутовало 250 истраживача запослених у научноистраживачке организације за рад на тестирању оболелих на присуство вируса у ковид 19 лабораторијама. НИО, које су под окриљем МПНТР-а, радиле су и на производњи визира и друге заштитне опреме, као и респиратора.

Кључне речи: ковид 19, сарс-ков-2, наука, епидемија, република србија

\section{ФОРМИРАНА РАДНА ГРУПА}

Радна група за прикупљање информација из научне литературе које се односе на ковид 19 формирана је 20. 3. 2020. године од стране Министарства просвете, науке и технолошког развоја Владе Републике Србије са циљем пласирања научно потврђених информација. Радном групом координишу др Марина Соковић, помоћник за науку у Министарству просвете, науке и технолошког развоја руководилац Сектора за науку, и проф. др Татјана Пекмезовић, продекан за науку Медицинског факултета Универзитета у Београду. У оквиру радне групе окупљени су реномирани научници из области које су релевантне за пандемију изазвану вирусом САРс-КОВ-2: медицине, фармације, биологије, молекуларне биологије, биохемије, хемије, физике, ветерине, пољопривреде и друге. Чланови радне групе су са научноистраживачких институција из целе Србије. Радна група је обухватила 22 истраживача.

У току своје активности радна група је добијала и информације од истраживача из дијаспоре, који су својим важним информацијама допринели да извештаји обухвате најновије научне чињенице и резултате. Путем међународне сарадње до радне групе су пристизале и информације, протоколи о коришћењу заштитне опреме, стерилизацији простора, начину понашања, превентиви, третману пацијената, досадашњим искуствима других земаља и много друге, који су од стране чланова радне групе превођени на српски језик, форматирани и слати на 
увид Кризном штабу. Радна група је од 23. 3. 2020. до 11. 5. 2020. године свакодневно достављала извештаје државном секретару за науку, проф. др Владимиру Поповићу, који је затим извештавао председницу Владе и Кризни штаб. Након овог периода радна група слала је извештаје два пута недељно, закључно са 20. 5. 2020. године.

Радна група је у току свог рада поднела извештаје из имунологије, епидемиологије, микробиологије, вирусологије, инфектологије, молекуларне биологије, хемије, фармације, медицине, етномедицине и других области и дисциплина. Поред сублимирања извештаја, базираних на објављеним стручним информацијама и резултатима из целога света, радна група предложила је Кризном штабу и неколико научних студија које су истраживачи из научноистраживачких организација послали радној групи.

\section{СТУДИЈЕ КОЈЕ СУ ПЛАСИРАНЕ ОД СТРАНЕ РАДНЕ ГРУПЕ}

\section{Испитивање серопозитивности и сопствени ЕЛИСА тестови}

\section{Организатор студије:}

ИНЕП

\author{
Руководилаи студије: \\ др Олгица Недић \\ др Сергеј Томић \\ др Марија Гњатовић
}

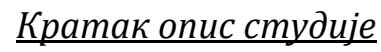

Седам дана након инфекције САРС-ЦоВ-2 појављују се ИгМ антитела, 7-14 дана долази до сероконверзије, односно промене класе антитела из ИгМ у ИгГ. Серолошке анализе важне су за: утврђивање акутне инфекције и процену квалитета имунског одговора (однос ИгМ/ИгГ антитела у серуму) (дијагностички значај), идентификацију радно способних особа које су се успешно избориле са инфекцијом, па могу значајно да помогну здравственом систему и економији Србије (економски и јавни јавноздравствени значај), проверу трајности имунске заштите организма или вакцинацији (развој вакцине и праћење), епидемиолошка испитивања која имају за циљ да се процени изложеност укупне популације одређеном инфективном агенсу (епидемиолошки значај), што је врло важно за процену колективног имунитета, откривање поремећаја у раду имунског система и идентификација имунокомпромитованих индивидуа, идентификација реконвалесцената који имају висок титар неутралишућих антитела (>1/40 титар ИгГ антитела) и могу бити донори плазме за терапију најугроженијих болесника, а који нису у стању да се самостално изборе са инфекцијом (терапијски значај). ИНЕП ради на развоју сопствених ЕЛИСА тестова, са различитим патогенима. 


\section{Национална епидемиолошка студија}

\section{Организатор студије}

Медицински факултет Универзитета у Београду (МФУБ)
Руководилац студије

проф. др Татјана Пекмезовић, проф. др Тања Јовановић

\section{Кратак опис студије}

Суштина сероепидемиолошког истраживања у овој фази епидемије у Србији је процена обима инфекције ковида 19 , који се утврђује серопозитивношћу код опште популације. Студија би дала допринос бољем познавању улоге асимптоматских инфекција у преношењу вируса САРС-ЦоВ-2 у хуманој популацији, имајући у виду чињеницу да ове карактеристике болести још увек нису сасвим познате. Студије спроведене у домаћинствима би могле такође бити изузетно значајан извор података о времену и вероватноћи трансмисије и могле би бити корисне у процени основне „стопе“ репродукције, кључног епидемиолошког параметра у разматрању епидемијског јављања болести у једној популацији. Такође, тестирање необјашњених кластера тешких случајева акутних респираторних инфекција, независно од података о путовањима, може бити значајно за откривање ланаца трансмисије који су пропуштени.

\section{Развој и производња домаћих синтетичких протеина гена ковида 19}

\section{Организатор студије}

Хемијски факултет у Београду

\section{Руководилац студије}

проф. др Тања Ћирковић Величковић проф. др Марија Гавровић-Јанкуловић проф. др Радивоје Продановић

Кратак опис студије

Истраживачи Хемијског факултета и Иновационог центра раде на производњи, пречишћавању и карактеризацији протеина САРс-ЦоВ-2 вируса. Прва количина протеина могла би бити готова до краја маја. Због велике потражње и високе цене ових протеина, односно китова за антигене у свету, производња сопствених, домаћих китова за антигене овог вируса знатно би убрзала тестирање пацијената и смањила цену тестова. Производња антигена се надовезује на пројекат који ради ИНЕП, производња сопствених ЕЛИС-а тестова, што све укупно знатно олакшава тестирање ковида 19 пацијената у Србији. Постоји и могућност извоза у друге земље. 


\section{Терапија са високим дозама интравенских имуноглобулина}

организатор студије

ИНЕП
Руководилац студије

др Љиљана Софронић Милосављевић, ИНЕП

др Милан Баста, имунолог из САД

др Оливера Савић, Институт за трансфузију крви Србије

\section{$\underline{\text { Kратак опис студије }}$}

АРДС је претерана, аутоагресивна реакција урођеног имунског система, конкретно система комплемента, који се ексцесивно активира и оштећује интегритет капиларно-алвеоларне баријере са последичним изливом инфламаторног ексудата у алвеоле и заустављањем дисајног процеса. Анафилатоксини ЦЗа, Ц5а и терминални мембрански комплекс (МАЦ или сЦ5б9) су кључни медијатори у патогенези АРДС. Значајан потенцијал у терапији АРДС-а има примена ИВИГ, који има моћни антиинфламаторни ефекат, посредован способношћу неспецифичних молекула имуноглобулина да се закаче за поменуте фрагменте комплемента и неутралишу их. Овај механизам дејства ИВИГ доказан је у многим комплемент-зависним обољењима, како класично аутоимуним тако и оним базираним на деструктивним инфламаторним реакцијама. ИВИГ би могао да спречи даље напредовање процеса који води смртном исходу. Праћење базалних и интервалских вредности фрагмената комплемента би била од значаја за корелисање са озбиљношћу болести, као и за праћење ефекта терапије.

\section{Формирање биобанке генетичких узорака пацијената са ковидом 19 у Србији}

\section{Организатор студије}

Институт за молекуларну генетику и генетичко инжењерство Универзитет у Београду (ИМГГИ)
Руководилаи студије

др Соња Павловић, научни саветник, ИМГГИ

\section{Kратак опис студије}

Искуство свих здравствених система широм света који су се суочили са 
епидемијом ковида 19 указује на то да постоји широки спектар клиничких слика код пацијената, било млађих или старијих. Такође је примећена и популациона специфичност. У ери геномике постало је јасно да би сусцептибилност и резистенција на САРС-ЦоВ-2 вирус, као и ток болести и одговор на експерименталне терапије, могли бити објашњени индивидуалном генетичком основом (ДНК запис) сваког пацијента. Први корак неопходан за истраживање интеракције CAPC-ЦоВ-19 вируса са човеком је формирање биобанки генетичких узорака пацијената оболелих од ковида 19. Пред Србијом је изазов и шанса да допринесе разумевању болести ковида 19 тако што ће уложити напор да формира такву биобанку.

\section{Специфичности хуморалног и ћелијског имунског одговора код пацијената са различитим клиничким степеном ковида 19}

\author{
Организатор студије \\ ИНЕП
}

\author{
Руководилац студије \\ др Сергеј Томић, ИНЕП \\ др Ђорђе Миљковић, ИБИСС
}

\section{Кратак опис студије}

Применом савремених имунолошких тестова могу да се идентификују имунолошки показатељи који су од значаја за праћење тока, прогнозе и исхода ковида 19. Најновији научни радови везани за имунски одговор у ковиду 19 указују на велики значај праћења хуморалног и ћелијског имунског одговора у току ове болести. Подаци показују да број Т лимфоцита у крви пацијената, поготово ЦД4+ и ЦД8+ Т лимфоцита, однос Т лимфоцита и гранулоцита, и др. имају значајну предиктивну вредност за развој тежег облика ковида 19 и ефикасности примењених терапија. Претпоставља се да су кључни патогени фактори у развоју мијелоидне ћелије ковида 19, посебно моноцити и гранулоцити. Постоји оправдана научна основа да се провери хипотеза да су у пацијената са тежом клиничком сликом ове ћелије кључни патогенетски фактор у супресији имунолошке реактивности и следствених клиничких консеквенци таквог стања. Ти механизми су већ изучавани и потврђени код сепсе и МОДС-а.

\section{БАЗА ИСТРАЖИВАЧА}

У току трајања ванредног стања Министарство просвете, науке и технолошког развоја сачинило је базу података истраживача који имају искуства у раду са тестовима RT PCR. Истраживачи су били са свих научноистраживачких институција које се баве PCR-ом, из области биологије, молекуларне биологије, 
хемије, ветерине, фармације, медицине, пољопривреде и других релевантних институција. Истраживачи су ангажовани у лабораторијама:

- Института за вирусологију, вакцине и серуме „Торлак“,

- Новооформљеној лабораторији „Нио-уап национална лабораторија за молекуларну детекцију инфективних агенаса Београд“ - Ватрено око, Клиничког центра Србије,

- Националној референтној лабораторији Батајница,

- Заводу за биоциде и медицинску екологију,

- Универзитету у Београду, Медицински факултет,

- Ветеринарски институти широм Србије.

База је обухватала 250 истраживача у свим научним звањима који су били спремни за рад на RT PCR у поменутим лабораторијама. Министарство је ради организовања бржег тестирања пацијената на присуство САРс-КОВ-2 вируса прикупило од научноистраживачких институција податке о броју и врсти:

- Екстракционих китова за изолацију RNA,

- PCR апарата,

- Замрзивача за складиштење узорака на -70 C.

\section{ФОНД ЗА ИНОВАЦИОНУ ДЕЛАТНОСТ}

Фонд за иновациону делатност у марту 2020. године расписао је јавни позив за финансијску подршку иновативним пројектима намењеним решавању проблема изазваним пандемијом ковида 19 (коронавирусом). Позив је био намењен микро, малим и средњим предузећима са већ развијеним прототиповима, производима, услугама и технологијама који могу бити скалирани у кратком временском периоду и постати доступни за примену у сузбијању последица насталих пандемијом. На јавни позив је у кратком временског периода пристигло близу 300 предлога иновативних пројеката, што је показало висок потенцијал наших иновативних предузећа. У временском периоду од месец дана развијено је и доступно за коришћење свих 12 решења, чији је циљ сузбијање ефеката пандемије изазване коронавирусом.

\section{ФОНД ЗА НАУКУ РЕПУБЛИКЕ СРБИЈЕ}

Специјални програм истраживања ковида 19 Фонда за науку Републике Србије расписан је јавним позивом у мају 2020. године и намењен је финансирању пројеката који ће допринети ефикасном научном одговору на пандемију ковида 19 и омогућити бољу спремност и реаговање на нове друштвене изазове. Програм је намењен истраживачима који су запослени у акредитованим НИО и подржава примењена научна истраживања, креирање интердисциплинарних и мултидисциплинарних тимова и конзорцијумско подношење пројеката. Пројекти 
у оквиру овог програма се подносе на унапред задате теме у оквиру три групације научних области:

- (био)медицинске науке;

- (био)медицинско инжењерство и информационе технологије;

- економска, социолошка, психолошка истраживања и управљање сложеним системима.

\section{ЗАКЉУЧАК}

Министарство просвете, науке и технолошког развоја је након проглашења пандемије проузроковане вирусом САРс-КОВ-2 и увођења ванредног стања у Републици Србији реаговало и предузело неколико активности. Оформљена је радна група за прикупљање информација из научне литературе за ковид 19. У оквиру групе било је ангажовано 23 истраживача из релевантних области, запослених у научноистраживачким институцијама широм Србије. Радна група извештавала је свакодневно о најновијим резултатима и научним информацијама објављеним у реномираним научним часописима у целом свету послала је неколико протокола о коришћењу заштитне опреме, превенцији, третману, са свих аспеката науке, пласирала је шест научних студија, од којих ће Србија имати здравствени, али и економски добитак и напредак. Након погоршања епидемиолошке ситуације у јуну радна група наставила је са извештавањем. Такође се разматрају нове студије предложене од стране научне заједнице. Министарство је регрутовала 250 истраживача искусних у раду са молекуларним техникама које су биле неопходне за тестирање пацијената који су учествовали у раду лабораторија ковида 19, где су научни радници још увек активни и раде на тестирању узорака пацијената. Фонд за иновациону делатност и Фонд за науку расписали су позиве за пројекте са темом борбе против вируса САРс-КОВ-2.

Одговор науке на пандемију изазвану вирусом САРс-КОВ-2 био је адекватан, благовремен и успешан. На основу изнетих чињеница наука ће у сарадњи са другим секторима знатно допринети успешном завршетку епидемије и ојачати постојеће капацитете научноистраживачке сфере у Србији. Допринос који су научници координисани Министарством просвете, науке и технолошког развоја дали у борби против вируса САРс-КОВ-2 свакако је наше друштво учинило спремнијим за потенцијалне нове претње.

„Морамо се навићи да на најважнијим раскрсницама не налазимо увек знакове“ Ернест Хемингвеј 


\section{RESPONCE BY SCIENCE TO THE EPIDEMIC CAUSED BY SARS- KOV-2 VIRUS}

Abstract: The Ministry of Education, Science and Technological Development (MESTD) of the Government of the Republic of Serbia started a series of activities immediately after the state of emergency was introduced in order to join the fight against the COVID-19 pandemic. In that regard the Working Group, made of scientist from various institutes and universities from Serbia, was formed in order to gather information from scientific literature which relate to the epidemic caused by SARS$\mathrm{KoV}-2$ virus. Their task was to analyze the most relevant scientific articles, as well as the newest reliable sources of information, and to deliver daily reports on key scientific insights on COVID-19 to the State Secretary for Science which was then forwarded to the Prime Minister of Republic of Serbia, the Crisis Staff and to the medical team. Besides scientific information, the Working Group also forwarded suggestions from researchers and research institutions and pointed to the possibility and willingness of scientist to invest their knowledge through various tests and treatments. The importance and possibility of implementation of some of the proposals by scientists was recognized, as were usage of blood plasma in treating less severe COVID-19 patients, treatment by intravenous immunoglobulin, establishment of a bio bank of samples from COVID-19 patients, manufacturing of domestic serological and ELISA tests, conducting a national epidemiological study, synthesis of protein complex of antigens which contribute in the infection, studies of the specificities of immune system response of patients with different clinical degree of COVID-19. All aforementioned studies are in progress and for now are successfully being implemented in patient treatment. Besides everyday reports, the Working Group also suggested to the Crisis Staff newest recommendations and protocols for disinfection of spaces, usage of protective equipment, prevention, tests and therapy, and it continues with its work. The Ministry recruited 250 researches employed in scientific institutions to work in laboratories on testing the infected on the presence of COVID-19. Scientific institutions, which work under the MESTD, worked on visor production and other protective equipment, as well as respirators.

Key words: covid-19, sars-kov-2, science, epidemic, republic of serbia 